\title{
ANALISIS EFEKTIVITAS LAJUR KHUSUS SEPEDA PADA KAWASAN TOMANG - CIDENG TIMUR
}

\author{
Devin', Giovanni Pranata $^{2}$, dan Johannes Susanto ${ }^{3}$ \\ ${ }^{1}$ Program Studi Sarjana Teknik Sipil, Universitas Tarumanagara, Jl. Letjen S. Parman No.1 Jakarta \\ devin.325150103@stu.untar.ac.id \\ ${ }^{2}$ Program Studi Sarjana Teknik Sipil, Universitas Tarumanagara, J1. Letjen S. Parman No.1 Jakarta \\ giovannip@ft.untar.ac.id \\ ${ }^{3}$ Program Studi Sarjana Teknik Sipil, Universitas Tarumanagara, Jl. Letjen S. Parman No.1 Jakarta \\ jo.susantobsp@gmail.com
}

Masuk: 11-01-2021, revisi: 01-02-2020, diterima untuk diterbitkan: 02-02-2021

\begin{abstract}
During this pandemic, cycling has become an increasingly popular activity in Indonesian society. more and more people are flocking to bike. The reasons are also various, some are cycling to avoid cramming on public transportation for fear of contracting the corona virus, some are aimed only at eliminating boredom while doing Work From Home (WFH). Cycling also has many benefits including reducing stress, reducing the risk of degenerative desease, controlling body weight, and increasing body strength, balance and muscle coordination. However, there are still many problems with free space on the bicycle paths in the Jakarta area. One of the problems on bicycle paths that is often encountered is the difficulty of making the bicycle paths become steering due to several reasons. Therefore, this study aims to determine the level of satisfaction of the people of Jakarta, especially bicycle lane users to the bicycle lanes that have been provided by the Government. This research was conducted directly by observing the research location. And distribute questionnaires to the public to determine the level of respondent satisfaction. Processing of data analysis used descriptive statistical methods with the help of the application of the Statistical Package for the Social Sciences (SPSS).
\end{abstract}

Keywords: bicycle lane; community satisfaction level; questionnaire; Statistical Package for the Social Sciences (SPSS).

\section{ABSTRAK}

Di masa pandemi ini, bersepeda menjadi kegiatan yang makin populer di lakukan oleh masyrakat Indonesia. semakin banyak orang berbondong-bondong untuk bersepeda. Alasannya pun beragam ada yang bersepeda untuk menghindari berdesakan di kendaraan umum karena takut tertular virus corona ada pula yang bertujuan hanya untuk menghilangkan kejenuhan selama melakukan Work From Home (WFH). Bersepeda juga memiliki banyak manfaat diantaranya adalah mengurangi stres, mengurangi risiko penyakit degeneratif, mengandalikan berat badan, dan meningkatkan kekuatan, keseimbangan, dan koordinasi otot tubuh. Akan tetapi masih terdapat banyak masalah pada lajur sepeda yang ada di kawasan jakarta ini. Salah satu masalah pada lajur sepeda yang sering dijumpai adalah sulitnya membuat lajur sepeda menjadi stelir dikarenakan oleh beberapa hal. Oleh sebab itu penelitian ini bertujuan untuk mengetahui tingkat kepuasan masyarakat jakarta khususnya para pengguna lajur sepeda terhadap lajur sepeda yang telah disediakan oleh Pemerintah. Penelitian ini dilakukan secara langsung dengan melakukan pengamatan di lokasi penelitian dan membagikan kuesioner kepada masyarakat untuk mengetahui tingkat kepuasan responden. Pengolahan analisis data menggunakan metode statistika deskriptif dengan bantuan aplikasi Statistical Package for the Social Sciences (SPSS).

Kata kunci: lajur sepeda; Tingkat kepuasan masyarakat; Kuesioner; Statistical Package for the Social Sciences (SPSS)

\section{PENDAHULUAN}

Bersepeda merupakan salah satu solusi efektif untuk menghindari penggunaan transportasi publik yang rawan akan keramaian (Budiman, 2020). Selain menjadi solusi yang efektif untuk menghindari keramaian yang terdapat pada transportasi publik bersepeda juga dapat meningkatkan kebugaran tubuh serta ramah terhadap lingkungan. Gaya hidup bersepeda sebagai implementasi konsep green harus dijaga agar tidak menjadi tren yang semakin lama 
meredup. Perlu penyediaan fasilitas penunjang yang dapat memberikan rasa aman dan nyaman dalam bersepeda (Arifiani, 2012). Akan tetapi masih banyak masalah yang dihadapi oleh para pesepeda di jakarta ini. Sehingga membuat masyarakat hanya melakukan kegiatan bersepeda pada hari libur atau pada saat Pembatasan Sosial Berskala Besar (PSBB). Sementara itu yang diharapkan adalah masyarakat bisa mengimplementasikan gaya hidup bersepeda menjadi kegiatan yang rutin dilakukan misalnya seperti bike to work. Ada beberapa faktor yang menyebabkan masyarakat belum dapat menggunakan sepeda pada kegiatan sehari-hari. Faktor itu adalah lajur bebas yang kurang efektif dikarenakan banyaknya hambatan samping seperti PKL yang berjualan, kendaraan yang parkir di lajur sepeda dan masih banyak lagi. Alasan utama pesepeda butuh lajur pesepeda adalah untuk meningkatkan keamanan. Namun dalam kenyataan, berada di lajur sepeda tidak selalu lebih aman (Pramudiarja, 2019). Hal ini dikarenakan masih banyaknya kendaraan bermotor yang tidak taat dengan memasuki lajur sepeda. Selain itu juga tidak ada pembatas jalan yang tegas memisahkan antara lajur sepeda dengan lajur kendaraan bermotor. Dengan adanya lajur sepeda di Jakarta ini tetapi bila dalam pelaksanaannya masih banyak terdapat kendala tentunya lajur sepeda yang telah dibangun ini akan menjadi tidak efektif. Dikarenakan para penggunanya yang bahkan enggan untuk bersepeda dikarenakan masih terdapat beberapa masalah yang terjadi pada lajur sepeda yang bisa menghambat atau mengancam keselamatan para penggunanya. Tujuan penelitian ini diharapkan dapat menganalisis tingkat kepuasan pengguna lajur sepeda pada kawasan Tomang - Cideng Timur. Sehingga segala kekurangannya bisa dijadikan evaluasi bagi instansi pemerintah. Sehingga bisa terciptanya lajur sepeda yang efektif dan masyarakat bisa menerapkan sepeda menjadi transportasi utama yang digunakan dalam kegiatan seharihari.

\section{Lajur sepeda}

Lajur sepeda menurut American Association Of State Highway and Transporting Official (AASHTO) adalah bagian dari jalan raya yang telah di desain secara khusus yang digunakan untuk pengguna sepeda dengan marka trotoar dan rambu biasanya ditujukan untuk 1 lajur saja dalam 1 arah yang sama dengan badan jalan lalu lintas, kecuali jika di desain khusus untuk 2 ruas jalan.

\section{Karakteristik pengguna sepeda}

Salah satu karakteristik pesepeda ialah adanya variasi di antara penggunanya. Hal ini mempengaruhi bagaimana pesepeda berperilaku saat berkendara dan berimplikasi terhadap kriteria fasilitas sepeda yang diperlukan. Secara umum, variasi ini dapat dibedakan berdasarkan motif perjalanan dan kemampuan serta kenyamanan bersepeda (AASHTO, 2012). Secara garis besar karakteristik pengguna sepeda dibedakan menjadi 2 yaitu Pesepeda Utilitarian adalah pengguna sepeda yang menggunakan sepeda untuk menunjang kegiatan sehari-hari seperti pergi untuk bekerja, pergi ke sekolah dan sebagainya. Pesepeda Rekreasi adalah pengguna sepeda yang menggunakan sepeda untuk dijadikan rekreasi, melepas kejenuhan kegiatan yang biasa dilakukan oleh pesepeda rekreasi seperti berolahraga pada saat "car free day" ataupun sekedar berjalan-jalan di komplek perumahan.

\section{Prinsip dasar perencanaan dan perancangan fasilitas bersepeda}

Keamanan, Kelangsungan rute, Keterpaduan, Kenyamanan, dan Menarik merupakan prinsip dasar dalam perencanaan dan perancangan fasilitas ramah bersepeda (CROW, 2017). Dalam penerapannya, seringkali perlu ada kompromi yang dilakukan untuk menentukan aspek prioritas. Di tahap perencanaan, hal ini ditentukan oleh fungsi jaringan sepeda yang ingin dikembangkan (PRESTO, 2007).Keamanan meliputi proteksi fisik, pemenuhan standar dimensi, rancangan simpang, pengendalian kecepatan. Kelangsungan rute meliputi perancangan rute yang lebih singkat dibandingkan kendaraan bermotor dan pemberian prioritas bagi pesepeda di penyebrangan dan persimpangan.keterpaduan meliputi pembuatan rute menerus dan tidak terputus dari titik awal ke tujuan pesepeda, penyediaan marka yang jelas dan menyediakan fasilitas parkir di tempat-tempat tujuan pesepeda.kenyamanan meliputi pembuatan permukaan lajur sepeda yang rata serta tidak licin, pembuatan lebar yang cukup pada lajur sepeda sehingga memungkinkan pesepeda untuk mendahului atau bersepeda berdampingan. Pembuatan lajur sepeda yang memudahkan pesepeda seperti menghindari tanjakan atau tikungan tajam, dan Menjaga lajur sepeda agar tetap terawat seperti bebas dari sampah,lubang serta genangan air.faktor menarik meliputi menciptakan rute yang melewati pusat kota, taman kota serta tempat rekreasi lainnya, menghindari untuk merancang rute di tempat yang rawan seperti tempat yang sepi atau kurang pencahayaan dan menciptakan desain dengan lingkungan sekitar yang estetik.

\section{Kebutuhan ruang pesepeda}

Kenyamanan pengguna sepeda sangat bergantung kepada ruang gerak bebasnya semakin besar ruang geraknya maka akan lebih nyaman dalam melakukan aktivitas bersepeda. berikut standar dimensi ruang sepeda dapat dilihat pada tabel 1 . 
Tabel 1. Standar dimensi dan kebutuhan ruang sepeda

\begin{tabular}{|c|c|c|c|}
\hline Komponen & Definisi & Dimensi & Keterangan \\
\hline Lebar sepeda & $\begin{array}{l}\text { Lebar yang dibutuhkan } \\
\text { sepeda saat diam }\end{array}$ & $0,7 \mathrm{~m}$ & $\begin{array}{l}\text { Untuk sepeda pada umumnya, } \\
\text { tidak termasuk sepeda dengan } \\
\text { modifikasi }\end{array}$ \\
\hline $\begin{array}{c}\text { Ruang } \\
\text { pergerakan }\end{array}$ & $\begin{array}{l}\text { Lebar yang dibutuhkan } \\
\text { untuk pergerakan kesamping } \\
\text { kiri dan kanan untuk } \\
\text { menjaga kestabilan laju } \\
\text { sepeda }\end{array}$ & $0,75-1 \mathrm{~m}$ & Semakin lebar di laju rendah \\
\hline $\begin{array}{l}\text { Jarak antar } \\
\text { pesepeda }\end{array}$ & $\begin{array}{l}\text { Lebar tambahan yang } \\
\text { dibutuhkan untuk } 2 \\
\text { pesepeda melaju } \\
\text { berdampingan dengan } \\
\text { nyaman }\end{array}$ & $0,5 \mathrm{~m}$ & Semakin lebar di lajur yang ramai \\
\hline $\begin{array}{l}\text { Jarak dengan } \\
\text { hambatan } \\
\text { samping }\end{array}$ & $\begin{array}{l}\text { Jarak minimal antara sepeda } \\
\text { dengan hambatan samping } \\
\text { (kerb, pagar,perbedaan } \\
\text { elevasi, dinding,atau lainnya }\end{array}$ & $\begin{array}{c}0,2 \mathrm{~m} \\
0,25 \mathrm{~m} \\
0,5 \mathrm{~m} \\
0,7 \mathrm{~m} \\
1 \mathrm{~m}\end{array}$ & $\begin{array}{c}\text { Tinggi hambatan samping < } 15 \\
\mathrm{~cm} \\
\text { Tinggi hambatan samping } 15-60 \\
\mathrm{~cm} \\
\text { Tinggi hambatan samping } 60- \\
100 \mathrm{~cm} \\
\text { Tinggi hambatan samping }>100 \\
\mathrm{~cm} \\
\text { Hambatan samping } \\
\text { merupakan } \\
\text { dinding tertutup }\end{array}$ \\
\hline
\end{tabular}

(Sumber : Institute for Transportation \& Development Policy, 2019)

\section{Fasilitas lajur sepeda}

Fasilitas pada lajur sepeda harus mengutamakan keamanan dan kenyamanan bagi pengguna sepeda. Ada beberapa kriteria yang harus dimiliki pada lajur sepeda antara lain adalah bebas dari kendaraan bermotor, aman dan nyaman serta dilengkapi dengan rambu serta marka yang jelas. Beberapa contoh fasilitas pada lajur sepeda antara lain adalah proteksi fisik, Pemilihan proteksi fisik pada lajur sepeda guna menciptakan lajur sepeda yang bebas dari kendaraan bermotor, berbeda-beda sesuai dengan tipe tepi badan jalan yang ada di setiap kawasan lalu pada perencanaan material permukaan juga dinilai sebagai aspek yang penting karena dapat menunjang keselamatan pengguna sepeda. Salah satu contohnya adalah penempatan arah manhole pada lajur sepeda yang seharusnya tegak lurus terhadap lajur sepeda. Pengecatan dan pemarkaan lajur sepeda yang dimana dalam perancangannya Pemarkaan harus terlihat jelas dan lengkap serta penempatannya harus sesuai dengan peruntukannya dan Warna yang digunakan untuk pemarkaan pada lajur sepeda harus seragam agar memudahkan pesepeda dalam memahami marka tersebut.rambu, Rambu harus terlihat jelas dan lengkap serta penempatannya harus sesuai dengan peruntukkannya. Rambu berfungsi memberikan informasi terkait peringatan, larangan, perintah, serta petunjuk saat berlalu lintas. Berikut ini merupakan beberapa rambu dasar yang terdapat pada lajur sepeda dan yang terakhir adalah fasilitas pelengkap seperti peneduh dirasa perlu diadakan mengingat teriknya cuaca di jakarta pada saat siang hari. Sehingga dengan adanya peneduh ini bisa membuat para pengguna sepeda lebih nyaman lagi dalam melakukan aktivitas bersepeda. Fasilitas penerangan juga diperlukan untuk menunjang keselamatan para pengguna sepeda yang beraktivitas pada malam hari.

\section{METODE PENELITIAN}

Metode pengumpulan data yang digunakan dalam penelitian ini adalah dengan melakukan penyebaran kuesioner secara online. Penelitian ini diawali dengan studi pendahuluan, tinjauan pustaka, penentuan lokasi penelitian, kemudian melakukan penyebaran kuesioner secara online dengan target pengguna sepeda khususnya yang menggunakan lajur sepeda pada kawasan Tomang-Cideng Timur. Setelah pengumpulan data selesai maka akan dilakukan analisis untuk mengetahui tingkat keefektifan lajur sepeda yang berada pada kawasan Tomang-Cideng 
Timur. Dari hasil analisis ini kemudian akan disusun kesimpulan dan saran. Desain penelitian ini menggunakan metode kualitatif yang diubah menjadi data kuantitatif dengan menggunakan skala likert. Lalu kemudian data kualitatif yang telah diubah menjadi data kuantitatif tersebut akan diolah dengan bantuan program SPSS. Dalam skala likert ini digunakan penilaian dalam bentuk angka 1 (satu) sampai 5 (lima). yaitu dimana 1 (satu) mewakilkan jawaban sangat tidak setuju sampai 5 (lima) mewakilkan jawaban sangat setuju.

\section{HASIL DAN PEMBAHASAN}

Pada awal perencanaan penyebaran kuesioner ini. Penulis menargetkan sebanyak 100 responden untuk dapat mengisi kuesioner yang penulis sebarkan ini. Akan tetapi pada realisasinya jumlah responden yang didapatkan adalah sebanyak 113 responden. Tetapi data yang dipakai oleh penulis hanya 100 data responden pertama. Dikarenakan sudah memenuhi kuota yang ditargetkan oleh penulis. Daftar pertanyaan yang disajikan penulis pada kuesioner yang disebarkan meliputi 2 variabel yaitu terkait karakteristik pesepeda (X1) dan terkait persepsi pesepeda terhadap lajur sepeda itu sendiri (X2) yang dapat dilihat pada tabel 2.

Tabel 2. Daftar pertanyaan kuesioner

\begin{tabular}{|c|c|}
\hline Variabel & Pertanyaan \\
\hline $\mathrm{X} 1.1$ & Saya menggunakan sepeda untuk menunjang kegiatan sehari-hari \\
\hline $\mathrm{X} 1.2$ & Saya menggunakan sepeda untuk sekedar berolahraga atau berekreasi \\
\hline $\mathrm{X} 1.3$ & Saya menggunakan sepeda secara individual \\
\hline $\mathrm{X} 1.4$ & Saya menggunakan sepeda secara berkelompok \\
\hline $\mathrm{X} 1.5$ & Saya menggunakan sepeda sepanjang hari atau pada saat jam sibuk \\
\hline $\mathrm{X} 1.6$ & Saya menggunakan sepeda hanya pada akhir pekan atau pada setelah jam sibuk \\
\hline $\mathrm{X} 1.7$ & Saya merasa percaya diri bersepeda pada kondisi lalu lintas dengan volume padat / Ramai \\
\hline $\mathrm{X} 1.8$ & Saya merasa kurang percaya diri bersepeda pada kondisi lalu lintas dengan volume padat/ramai \\
\hline $\mathrm{X} 1.9$ & Saya bersepeda dengan kecepatan tinggi $(>10 \mathrm{~km} / \mathrm{jam})$ \\
\hline $\mathrm{X} 1.10$ & Saya bersepeda dengan kecepatan rendah $(<10 \mathrm{~km} / \mathrm{jam})$ \\
\hline $\mathrm{X} 2.1$ & Saya merasa lebar lajur sepeda Tomang - Cideng Timur aman untuk digunakan \\
\hline $\mathrm{X} 2.2$ & Saya merasa lebar lajur sepeda Tomang - Cideng Timur nyaman untuk digunakan \\
\hline $\mathrm{X} 2.3$ & $\begin{array}{c}\text { Saya merasa lajur sepeda Tomang - Cideng Timur steril dari kendaraan bermotor serta hambatan } \\
\text { lainnya }\end{array}$ \\
\hline $\mathrm{X} 2.4$ & Saya merasa aman pada saat melintasi persimpangan di lajur sepeda Tomang - Cideng Timur \\
\hline $\mathrm{X} 2.5$ & $\begin{array}{c}\text { Saya merasa rute pada lajur sepeda Tomang - Cideng Timur lebih singkat daripada rute jalur } \\
\text { kendaraan bermotor ( contoh: dapat langsung melintasi persimpangan tanpa perlu memutar seperti } \\
\text { kendaraan bermotor ) }\end{array}$ \\
\hline $\mathrm{X} 2.6$ & Saya merasa di prioritaskan sebagai pengguna sepeda di lajur sepeda Tomang - Cideng Timur \\
\hline $\mathrm{X} 2.7$ & $\begin{array}{c}\text { Saya merasa puas dengan keadaan permukaan lajur sepeda Tomang - Cideng Timur ( contoh: apakah } \\
\text { permukaannya rata/tidak, licin/tidak) }\end{array}$ \\
\hline $\mathrm{X} 2.8$ & $\begin{array}{c}\text { Saya merasa puas dengan lajur sepeda Tomang - Cideng Timur yang terawat ( contoh: bebas dari } \\
\text { sampah, lubang, genangan air dll) }\end{array}$ \\
\hline $\mathrm{X} 2.9$ & $\begin{array}{c}\text { Saya merasa puas dengan adanya peneduh (contoh: pohon) di sepanjang lajur sepeda Tomang - } \\
\text { Cideng Timur }\end{array}$ \\
\hline $\mathrm{X} 2.10$ & $\begin{array}{c}\text { Saya merasa puas dengan adanya penerangan (contoh: lampu jalan) di sepanjang lajur sepeda Tomang } \\
\text { - Cideng Timur }\end{array}$ \\
\hline
\end{tabular}


Tabel 2. Daftar pertanyaan kuesioner (lanjutan)

\begin{tabular}{cc}
\hline Variabel & Pertanyaan \\
\hline X2.11 & Saya merasa puas dengan marka yang jelas di sepanjang lajur sepeda Tomang - Cideng Timur \\
X2.12 & Saya merasa puas dengan rambu yang jelas di sepanjang lajur sepeda Tomang - Cideng Timur \\
X2.13 & Saya akan merasa lebih aman bila terdapat "proteksi fisik" yang memisahkan lajur sepeda dengan lajur \\
& kendaraan bermotor \\
\hline
\end{tabular}

Tiap pertanyaan akan dijawab dengan 5 pilihan jawaban yaitu STS (Sangat tidak setuju), TS (Tidak setuju), N (Netral), S (Setuju), SS (Sangat Setuju). Dan bersifat wajib untuk dijawab. Tetapi untuk pertanyaan mengenai saran responden dapat menuliskan sarannya dengan bebas tanpa berpaku pada jawaban yang telah di sediakan seperti butir pertanyaan lainnya, dan pertanyaan mengenai saran ini bersifat tidak wajib untuk dijawab dalam artian apabila responden tidak memiliki saran, responden dapat melewati pertanyaan ini. Terdapat juga uji validitas dan uji reliabilitas terhadap kuesioner ini, yang dapat dilihat pada tabel 3 dan tabel 4.

Tabel 3. Uji validitas

\begin{tabular}{ccc}
\hline Variabel & R hitung \\
\hline X2.1 & Pearson Correlation & 0,625 \\
X2.2 & Pearson Correlation & 0,612 \\
X2.3 & Pearson Correlation & 0,537 \\
X2.4 & Pearson Correlation & 0,635 \\
X2.5 & Pearson Correlation & 0,619 \\
X2.6 & Pearson Correlation & 0,563 \\
X2.7 & Pearson Correlation & 0,539 \\
X2.8 & Pearson Correlation & 0,548 \\
X2.9 & Pearson Correlation & 0,672 \\
X2.10 & Pearson Correlation & 0,624 \\
X2.11 & Pearson Correlation & 0,546 \\
X2.12 & Pearson Correlation & 0,575 \\
X2.13 & Pearson Correlation & 0,264 \\
\hline
\end{tabular}

Tabel 4. Uji reliabilitas

\begin{tabular}{cc}
\hline Cronbach's Alpha & Nof items \\
\hline 0,783 & 23 \\
\hline
\end{tabular}

Berikut akan penulis tampilkan hasil analisis pada tabel 5 yaitu berupa hasil tertinggi dari tiap butir pertanyaan, walaupun terdapat 5 jawaban pada tiap pertanyaan yaitu pilihan sangat tidak setuju sampai pilihan sangat setuju, tetapi dalam jurnal ini penulis hanya akan menampilkan hasil tertinggi dari masing-masing pertanyaan tersebut. 
Tabel 5. Hasil pengumpulan data

\begin{tabular}{ccc}
\hline Variabel & Jawaban terbanyak & persentase \\
\hline X1.1 & Tidak Setuju & $35 \%$ \\
X1.2 & Setuju & $57 \%$ \\
X1.3 & Setuju & $48 \%$ \\
X1.4 & Setuju & $31 \%$ \\
X1.5 & Tidak Setuju & $42 \%$ \\
X1.6 & Setuju & $49 \%$ \\
X1.7 & Tidak Setuju & $39 \%$ \\
X1.8 & Setuju & $44 \%$ \\
X1.9 & Tidak Setuju & $31 \%$ \\
X1.10 & Setuju & $40 \%$ \\
X2.1 & Netral & $44 \%$ \\
X2.2 & Setuju & $43 \%$ \\
X2.3 & Netral & $37 \%$ \\
X2.4 & Netral & $35 \%$ \\
X2.5 & Setuju & $45 \%$ \\
X2.6 & Setuju & $44 \%$ \\
X2.7 & Netral & $44 \%$ \\
X2.8 & Netral & $41 \%$ \\
X2.9 & Setuju & $44 \%$ \\
X2.10 & Setuju & $53 \%$ \\
X2.11 & Setuju & $66 \%$ \\
X2.12 & Setuju & $72 \%$ \\
X2.13 & Setuju & $52 \%$ \\
\hline & & \\
\hline & & \\
\hline
\end{tabular}

Setelah memperoleh hasil analisis, akan dilakukan perhitungan rata-rata berbobot dari tiap pernyataan, berikut adalah hasil perhitungan rata-rata berbobot dari tiap pernyataan yang dapat dilihat pada tabel 6 .

Tabel 6. Hasil perhitungan rata-rata berbobot

\begin{tabular}{cc}
\hline Variabel & Nilai Rata-rata berbobot \\
\hline X1.1 & 2,2 \\
X1.2 & 3,43 \\
X1.3 & 3,45 \\
X1.4 & 2,89 \\
X1.5 & 1,92 \\
X1.6 & 3,42 \\
X1.7 & 2,32 \\
X1.8 & 3,5 \\
\hline
\end{tabular}


Tabel 6. Hasil perhitungan rata-rata berbobot (lanjutan)

\begin{tabular}{cc}
\hline Variabel & Nilai Rata-rata berbobot \\
\hline X1.9 & 2,7 \\
X1.10 & 3,27 \\
X2.1 & 3,18 \\
X2.2 & 3,35 \\
X2.3 & 2,67 \\
X2.4 & 2,81 \\
X2.5 & 3,44 \\
X2.6 & 3,28 \\
X2.7 & 3,33 \\
X2.8 & 3,2 \\
X2.9 & 3,48 \\
X2.10 & 3,59 \\
X2.11 & 3,84 \\
X2.12 & 3,87 \\
X2.13 & 4,07 \\
\hline
\end{tabular}

Dari perhitungan rata-rata terbobot kemudian diperhitungkan kembali rata-rata pada hasil rata-rata terbobot pada variabel X2 guna mengetahui apakah lajur khusus sepeda pada kawasan ini sudah efektif atau belum dan didapatkan hasil rata-rata nya sebesar 3,39. selain itu terdapat juga saran yang diberikan oleh responden yang dapat dilihat pada tabel 7.

Tabel 7. Saran

\begin{tabular}{cr}
\hline No & Saran \\
\hline 1 & Memberi proteksi fisik pada lajur khusus sepeda berupa kanstin \\
2 & Memberbanyak rambu pada lajur khusus sepeda \\
3 & Membuat peraturan tentang parkir kendaraan yang hanya dilakukan pada jam-jam tertentu saja \\
4 & Memperketat sanksi bagi pelanggar yang memasuki lajur sepeda \\
5 & Pembuatan marka yang lebih jelas lagi \\
6 & Memaksimalkan penggunaan dana yang telah disediakan untuk lajur sepeda \\
7 & Meningkatkan pengawasan agar lajur sepeda bisa lebih tertib lagi \\
8 & Mengedepankan faktor keamanan seperti pemasangan CCTV \\
9 & Pemisahan lajur sepeda yang terpisah dari lajur pejalan kaki \\
10 & Memperbesar dimensi dari lajur khusus sepeda \\
\hline
\end{tabular}

\section{KESIMPULAN DAN SARAN}

\section{Kesimpulan}

Berdasarkan penelitian yang dilakukan dengan cara menyebarkan kuesioner secara online melalui google form dapat diambil poin-poin kesimpulan sebagai berikut: 
1. Berdasarkan hasil penelitian dan analisis terhadap tingkat keamanan pada lajur khusus sepeda di kawasan Tomang-Cideng timur ini didapatkan nilai rata-rata berbobot sebesar 3,18. Oleh sebab itu lajur khusus sepeda pada kawasan ini dinilai sudah cukup aman.

2. Berdasarkan hasil penelitian dan analisis terhadap tingkat kenyamanan pada lajur khusus sepeda pada kawasan Tomang-Cideng timur ini didapatkan nilai rata-rata berbobot sebesar 3,35. Oleh sebab itu kesimpulan yang bisa diambil adalah lajur sepeda pada kawasan ini dinilai sudah cukup nyaman untuk digunakan.

3. Berdasarkan hasil penelitian dan analisis terhadap tingkat kesterilan pada lajur khusus sepeda pada kawasan Tomang-Cideng timur ini didapatkan nilai rata-rata berbobot sebesar 2,67. Oleh sebab itu lajur khusus sepeda pada kawasan ini dinilai tidak steril dikarenakan beberapa faktor seperti masih adanya pedagang kaki lima,kendaraan bermotor yang tidak taat dan kendaraan yang parkir di lajur khusus sepeda. Hal ini juga sangat terlihat pada saat penulis melakukan survey langsung pada lajur tersebut yang memang masih jauh dari kata steril.

4. Berdasarkan hasil penelitian dan analisis terhadap tingkat keamanan pada saat melintasi persimpangan pada lajur khusus sepeda pada kawasan Tomang-Cideng timur ini didapatkan nilai rata-rata berbobot sebesar 2,81 . Hal ini membuktikan bahwa lajur sepeda yang melintasi persimpangan pada kawasan ini dinilai belum cukup aman untuk dilalui para pengguna sepeda.

5. Berdasarkan hasil penelitian dan analisis terhadap penilaian rute yang dinilai lebih singkat pada lajur khusus sepeda pada kawasan Tomang-Cideng timur ini didapatkan nilai rata-rata berbobot sebesar 3,44. Hal ini membuktikan bahwa lajur sepeda memiliki rute yang lebih singkat daripada rute kendaraan bermotor.

6. Berdasarkan hasil penelitian dan analisis terhadap rasa diprioritaskan pada lajur khusus sepeda pada kawasan Tomang-Cideng timur ini didapatkan nilai rata-rata berbobot sebesar 3,28. Hal ini membuktikan bahwa pengguna lajur sepeda pada kawasan ini sudah merasa di prioritaskan.

7. Berdasarkan hasil penelitian dan analisis terhadap permukaan lajur pada lajur khusus sepeda pada kawasan Tomang-Cideng timur ini didapatkan nilai rata-rata berbobot sebesar 3,33. oleh sebab itu penilaian terhadap permukaan lajur pada lajur khusus sepeda ini dinilai sudah cukup baik untuk digunakan.

8. Berdasarkan hasil penelitian dan analisis terhadap keterawatan lajur pada lajur khusus sepeda pada kawasan Tomang-Cideng timur ini didapatkan nilai rata-rata berbobot sebesar 3,2. oleh sebab itu penilaian terhadap keterawatan lajur pada lajur khusus sepeda ini dinilai sudah cukup baik.

9. Berdasarkan hasil penelitian dan analisis terhadap faktor peneduh yang terdapat pada lajur khusus sepeda pada kawasan Tomang-Cideng timur ini didapatkan nilai rata-rata berbobot sebesar 3,48. oleh sebab itu kesimpulan yang bisa diambil adalah faktor peneduh pada lajur sepeda di kawasan ini dinilai sudah cukup baik.

10.Berdasarkan hasil penelitian dan analisis terhadap faktor penerangan yang terdapat pada lajur khusus sepeda pada kawasan Tomang-Cideng timur ini didapatkan nilai rata-rata berbobot sebesar 3,59. oleh sebab itu kesimpulan yang bisa diambil adalah faktor penerangan pada lajur sepeda di kawasan ini dinilai sudah cukup baik.

11.Berdasarkan hasil penelitian dan analisis terhadap kejelasan marka yang terdapat pada lajur khusus sepeda pada kawasan Tomang-Cideng timur ini didapatkan nilai rata-rata berbobot sebesar 3,84. oleh sebab itu kesimpulan yang bisa diambil adalah kejelasan marka pada lajur khusus sepeda ini dinilai sudah cukup jelas dan baik.

12.Berdasarkan hasil penelitian dan analisis terhadap kejelasan rambu yang terdapat pada lajur khusus sepeda pada kawasan Tomang-Cideng timur ini didapatkan nilai rata-rata berbobot sebesar 3,87. oleh sebab itu kesimpulan yang bisa diambil adalah kejelasan rambu pada lajur khusus sepeda ini dinilai sudah cukup jelas dan baik.

13.Berdasarkan hasil penelitian dan analisis terhadap perlunya proteksi fisik yang terdapat pada lajur khusus sepeda pada kawasan Tomang-Cideng timur ini didapatkan nilai rata-rata berbobot sebesar 4,07. oleh sebab itu kesimpulan yang bisa diambil adalah perlunya dipasang proteksi fisik pada lajur khusus sepeda pada kawasan ini.

Jadi nilai rata-rata berbobot untuk penilaian terhadap lajur sepeda pada kawasan Tomang-Cideng Timur ini mendapatkan nilai rata-rata sebesar 3,39. oleh sebab itu lajur sepeda pada kawasan ini dinilai sudah cukup efektif. Walaupun masih terdapat beberapa kekurangan seperti kurangnya rasa aman bagi para pesepeda saat melintasi persimpangan, dan juga tidak sterilnya lajur sepeda dikarenakan masih banyak terdapat pengguna kendaraan bermotor yang tidak patuh pada peraturan seperti memasuki lajur khusus sepeda, memarkirkan kendaraannya di lajur sepeda dan juga masih adanya pedagang kaki lima pada lajur sepeda yang menjadi hambatan bagi lajur sepeda itu sendiri. 


\section{Saran}

Berdasarkan kesimpulan yang telah dibuat dinilai masih terdapat kekurangan yang terdapat pada lajur sepeda di kawasan ini oleh sebab itu terdapat beberapa saran untuk lajur sepeda ini seperti berikut:

1. Sangat perlunya diberikan proteksi fisik yang memisahkan antara lajur khusus sepeda dengan lajur kendaraan bermotor agar pengguna lajur ini dapat merasa lebih aman dan nyaman lagi dalam melakukan kegiatan bersepedanya pada kawasan ini.

2. Perlunya tindakan langsung dari aparat yang berwajib terhadap pelanggar di lajur khusus sepeda pada kawasan ini. Karena masalah utama yang dihadapi laju khusus sepeda pada kawasan ini maupun pada kawasan lain yang penulis amati adalah kurang sterilnya lajur khusus sepeda ini dikarenakan masih banyak para pengguna kendaraan bermotor yang tidak patuh terhadap peraturan. Oleh sebab itu para pelanggar sebaiknya diberikan efek jera agar bisa menjaga kesterilan lajur khusus sepeda ini.

3. Perlunya menjaga kebersihan pada lajur khusus sepeda pada kawasan ini agar menciptakan lajur sepeda yang lebih bersih lagi dan lebih nyaman lagi digunakan untuk para penggunanya.

\section{DAFTAR PUSTAKA}

AASHTO. GUIDE FOR THE DEVELOPMENT OF BICYCLE FACILITIES. America: AASHTO, 2012.

Arifiani, Rida Agniya. EVALUASI PENGELOLAAN LANSKAP LAJUR SEPEDA DI SENTUL CITY, BOGOR. Bogor: Institut Pertanian Bogor, 2012.

Budiman, Dicky. HOBI BERSEPEDA SELAMA PANDEMI CORONA, KESADARAN ATAU HANYA LATAH? 226 2020. <https://www.kompas.com/tren/read/2020/06/22/191500765/hobi-bersepeda-selamapandemi-corona-kesadaran-atau-hanya-latah-?page=all $>$.

CROW, Fistberaad. DESIGN MANUAL FOR BICYCLE Netherlands: CROW, 2017.

ITDP. PANDUAN JAKARTA RAMAH BERSEPEDA. Indonesia: ITDP, 2019.

Pramudiarja, AN Uyung. 5 ALASAN BANYAK PESEPEDA 'OGAH' PAKAI LAJUR SEPEDA. 30122019. $<$ https://health.detik.com/kebugaran/d-4839803/5-alasan-banyak-pesepeda-ogah-pakai- lajur -sepeda>.

$\begin{array}{lllll}\text { PRESTO. } & \text { PRESTO } & \text {.CYCLING } & \text { POLICY } & \text { GUIDE. }\end{array}$ 
